\title{
Respon Netizen terhadap Dakwah bi al-Qalam K.H. Muhammad Arifin Ilham di Media Sosial
}

\author{
Siti Tarwiah* \& Uwes Fatoni \\ Jurusan Komunikasi dan Penyiaran Islam, Fakultas Dakwah dan Komunikasi, \\ UIN Sunan Gunung Djati, Bandung \\ *Email:s_tarwiab@yahoo.com
}

\begin{abstract}
ABSTRAK
Penelitian ini mendiskusikan respon netizen terhadap dakwah bi al-qalam ustadz Arifin Ilham di media sosial Facebook. Dengan tujuan untuk mengetahui perhatian, pengertian, dan penerimaan dari netizen terhadap dakwah bi al-qalam ustadz Arifin Ilham. Penelitian ini menggunakan metode analisis isi kualitatif, yaitu menganalisis data berupa komentar-komentar yang diberikan netizen melalui simbol emotikon dan komentar. Berdasarkan hasil penelitian ditemukan: 1) Perhatian netizen dalam memberikan respon terhadap dakwah bi al-qalam ustadz Arifin Ilham berupa respon emotikon dan komentar, 2) Pengertian netizen dalam bentuk komentar positif, negatif, netral, dan tidak sesuai tema, 3) Penerimaan netizen berupa keinginan untuk berubah menjadi lebih baik, yaitu terhindar dari aqidah yang menyimpang, semakin rajin beribadah, dan semakin baik akhlaknya.
\end{abstract}

Kata Kunci : Dakwah, Respon, Media Sosial.

\section{ABSTRACT}

This study discusses the netizen response to the preaching ustadz. Arifin Ilham in social media. With the aim to know the attention, understanding, and acceptance of netizens against preaching bi al-qalam of ustadz. Arifin Ilham. This research uses qualitative content analysis method, which is analyzing data in the form of comments given by netizens through emoticons symbol and comment. Based on the research results found: 1) Attention netizen in giving response to da'wah bi al-qalam ustadz. Arifin Ilham in emoticons responses and comments, 2) Understanding of positive comments, negative, neutral, and not according to theme, 3) Acceptance of desire changed for the better, that is to avoid the aqidah deviant, the more diligent worship, and the better morals.

Keywords: Da'wah, Response, Social Media. 
Siti Tarwiah \& Uwes Fatoni

\section{PENDAHULUAN}

Dakwah merupakan suatu keharusan dalam rangka mengemban agama, dakwah harus dilakukan sesuai dengan perkembangan zaman sekarang yang sudah maju dalam hal sains dan teknologi, sebab aktifitas dakwah yang maju akan membawa pengaruh terhadap kemajuan agama dan sebaliknya, aktifitas dakwah yang lesu akan berakibat pada kemunduran agama. Karena adanya hubungan timbal balik seperti itu maka dapat dimengerti jika Islam meletakkan kewajiban dakwah kepada setiap pemeluknya. Kemajuan dan kemunduran umat Islam sangat berkaitan erat dengan kegiatan Dakwah yang dilakukannya.

Dakwah bi al-qalam (tulisan) merupakan salah satu jenis dari kegiatan dakwah. Menurut Al-Hasani (2006: xv) dan Amin (2008: 12) dakwah bi alqalam adalah "dakwah melalui tulisan yang dilakukan dengan keahlian menulis di media massa seperti surat kabar, majalah, buku, maupun internet".

Dakwah pada dasarnya adalah upaya untuk menumbuhkan kecendrungan dan ketertarikan terhadap apa yang selalu diserukan Islam. Dengan seiring perkembangan zaman kegiatan berdakwah dapat dilakukan melalui berbagai media yang ada (Nasrullah dan Sari, 2012) dan salah satunya adalah dengan menggunakan media sosial.

Menurut Utari (2011: 51) media sosial adalah sebuah media online dimana para penggunanya dapat dengan mudah berpartisipasi. Berpartisipasi dalam arti seseorang akan dengan mudah berbagi informasi, menciptakan konten atau isi yang ingi disampaikan kepada orang lain, memberi komentar terhadap masukan yang diterimanya dan seterusnya. Semua dapat dilakukan dengan cepat dan tak terbatas.

Media sosial saat ini sangat digemari oleh semua kalangan dari yang muda sampai yang tua. Selain itu, media sosial juga telah dijadikan sebagai alat untuk berdakwah bagi para da'i. Berdakwah melalui media sosial tergolong cukup mudah dan sangat praktis bukan hanya jangkauannya yang sangat luas. Telah banyak berbagai situs yang dijadikan sebagai media dakwah yaitu twitter, facebook, instagram, dan lain-lain.

Salah satu fenomena yang menjadi trend saat ini adalah dakwah melalui Facebook, karena semua lapisan masyarakat dari anak-anak, remaja, hingga dewasa memliki akun Facebook. Media sosial Facebook mempunyai beberapa kelebihan diantaranya, bisa digunakan sebagai chatting, mengirim pesan ke semua teman, update info, update kegiatan, mengirim artikel, 
mencari teman untuk dijadikan anggota group. Dengan chatting kita bisa melakukan dakwah fardhiyah, sehingga pendekatan kita lebih inten dan ikatan persaudaraan akan semakin kuat.

Selain mempunyai kelebihan, media sosial Facebook juga mempunyai kekurangan yaitu sering digunakan sebagai ajang penipuan seperti dalam berita yang dimuat pada harian republika yang di akses pada tanggal 11 Agustus 2015, selanjutnya dijadikan sebagai ajang penculikan yang dimuat beritanya di indosiar dan di akses pada tanggal 11 Agustus 2015. Kemudian Facebook juga dijadikan sebagai ajang penjualan diri yang dimuat di harian tribunnews yang di akses pada tanggal 11 Agustus 2015.

Menurut Ridwan Kamil (2014: 75) pada akhir 2013, pengguna aktif Facebook telah menembus angka 1,19 miliar orang. Jumlah ini kemungkinan besar akan terus bertambah. Menurut data statistik dari International Telecommunication Union (ITU), sampai akhir 2014, sebanyak tiga miliar manusia di dunia akan terkoneksi dengan internet. Sebanyak 1,3 miliar diantaranya menggunakan Facebook (statisticbrain.com/facebookstatistics).

Berdasarkan observasi sementara, jumlah pengguna aktif Facebook di Indonesia tiap bulannya mencapai 69 juta orang di lihat melalui (http://tekno.kompas.com) dan di daerah Bandung mencapai hampir 3 juta pengguna atau sekitar 30\% dari total pengguna Facebook di Jawa Barat, hasil ini di lihat melalui (http:/ / www.balebandung.com)

Alasan-alasan tersebut sudah cukup menjadi bukti, bahwa Facebook sangat urgen dalam proses penyampaian dakwah. Terutama di zaman berteknologi canggih seperti ini telah banyak para da'i yang menggunakan media Facebook sebagai ajang dakwahnya. Salah satunya seperti dakwah yang dilakukan Ustadz Arifin Ilham melalui halaman facebooknya (fane page) K.H. Muhammad Arifin Ilham. Halaman Facebook K.H. Muhammad Arifin Ilham berisikan update tentang pesan-pesan Dakwah yang bisa berdampak positif bagi pembacanya.

Ustadz Muhammad Arifin Ilham adalah seorang mubaligh yang lahir di Banjarmasin pada tanggal 8 Juni 1969. Ustadz Arifin Ilham memiliki majelis dzikir yang bernama Majelis Az-Zikra. Dakwah yang ia lakukan banyak di berbagai tempat yaitu televisi, masjid, dan sebagainya. Kegiatan dari dakwahnya secara off air yaitu halaqoh ilmu ba'da subuh setiap senin sampai dengan jum'at, kajian muslimah setiap hari kamis, tausiyah dan zikir akbar, masjid Az-Zikra tiap hari minggu pertama, sport sprituality, tausiyah dan berolahraga (futsal, badminton, bersepeda dan catur) dan perjalanan 
Siti Tarwiah \& Uwes Fatoni

dakwah seluruh nusantara.

Selain melakukan Dakwahnya di dunia nyata, ia juga melakukan dakwahnya melalui dunia maya dan salah satunya yaitu Facebook. Ia mulai menggunakan Facebook untuk berdakwah dari tahun 2009 dan sampai sejauh ini ia masih aktif menyampaikan pesan dakwahnya di media sosial Facebook. Di halaman facebooknya, ustadz Arifin Ilham gemar memosting dakwahnya yang berisikan tentang do'a-do'a, ibadah, hadits, dan lain-lain yang membuat pengguna Facebook menjadi lebih mengetahui tentang agama Islam.

Sementara itu, dari segmentasi pengguna Facebook adalah remajadewasa dengan rentan usia 18-34, seperti yang dikatakan Ridwan Kamil (2014: 75) dalam bukunya "Tetot" bahwa pengguna terbesar Facebook ada pada rentang usia 18-34 tahun, yaitu sebanyak 48 persen di lihat melalui (statisticbrain.com/facebook-statistics). Sehingga bisa dikatakan bahwa segmentasinya adalah pemuda (generasi muda).

Generasi muda adalah generasi penerus bangsa yang nantinya sebagai pemegang nasib bangsa ini, maka generasi mudalah yang menentukan semua apa yang dicita-citakan bangsa dan negara ini. Bila generasi muda telah dipercaya dan mempunyai rasa tanggung jawab yang tinggi dalam memperjuangkan amanah itu maka suatu bangsa tidak akan sia-sia dalam mendidik generasi tersebut.

Di zaman sekarang telah banyak masyarakat yang aktif di dunia maya (internet) salah satunya yaitu generasi muda. Pengguna aktif internet disebut juga netizen, karena netizen merupakan istilah yang akrab di dunia maya. Istilah netizen terbentuk dari dua kata yaitu Net yang berarti Internet dan kata Citizen yang bermakna Warga. Jadi, jika disatukan kurang lebih "Warga Internet" atau "Masyarakat Dunia Internet".

Netizen adalah siapa saja yang mengakses dan menggunakan internet. Mulai dari ABG yang sangat aktif mobile chatting menggunakan ebuddy atau bahkan berjam-jam membuka halaman facebook, mahasiswa yang bersuara kritis melalui media blog hingga para kaum dewasa-tua yang mengakses Facebook untuk mencari teman-temannya yang 'telah hilang', blogger, pengguna twitter, pengguna Facebook dan 'aktivis' sosial media lainnya termasuk dalam kategori netizens.

Selain dari yang disebutkan di atas para netizen juga belajar ilmu agama melalui internet salah satunya yaitu Facebook. Mereka menyukai halaman Facebook dari para da'i yang menggunakan media tersebut sebagai media dakwahnya dan contohnya seperti yang telah dijelaskan sebelumnya 
yaitu ustadz Arifin Ilham menggunakan media sosial Facebook sebagai salah satu media dakwahnya.

Di era yang modern ini, dengan adanya kegiatan dakwah di media sosial seperti yang dilakukan ustadz Arifin Ilham, masyarakat atau para netizen bisa menjadikan dakwah di media sosial tersebut sebagai pelengkap setelah melihat ceramah di televisi, mendengarkannya di radio, mengikuti pengajian, dan lain-lain. Dalam berbagai jejaring sosial ustadz Arifin Ilham memiliki fans yang banyak seperti di lihat di akun facebooknya, ustadz Arifin Ilham memiliki 4.530.313 likers dan di akun twitternya 622 ribu followers (jumlah tersebut berubah-rubah).

Jika kita lihat dari berbagai media sosial milik ustadz Arifin Ilham, bisa dikatakan beliau termasuk pendakwah yang sangat sukses. Terbukti dengan banyaknya penggermar yang menyukai dakwahnya tidak hanya di Facebook atau twitternya dalam realitanya saja penggemar ustadz Arifin Ilham banyak dari berbagai daerah mulai dari kalangan atas, menengah, sampai bawah dan dari yang tua hingga yang muda.

Dari gambaran diatas, penulis tertarik untuk mengetahui sejauh mana respon netizen pada bulan Februari khususnya yang menyukai halaman Facebook ustadz Arifin Ilham terhadap dakwah bi al-qalam ustadz Arifin Ilham agar dapat meningkatkan nilai-nilai keimanan, akhlak, dan moral yang berhubungan dengan perhatian, pengertian, dan penerimaan netizen terhadap dakwahnya ustadz Arifin Ilham di halaman facebooknya.

Dalam penelitian ini, telah ada penelitian yang sudah dilakukan sebelumnya, yang memiliki permasalah yang sama dengan yang akan diteliti. Berikut adalah penelitian yang memiliki persamaan dan perbedaan dengan penelitian yang akan diteliti.

Skripsi berjudul: "Respon Mahasiswa Terhadap Pesan Dakwah Dalam Lagu Nasyid Opick (Studi Deskriptif Di "Pondok Ibu Haji" Jl. Manisi Gg. Bhakti 1 No. 50 Kelurahan Cipadung Kecamatan Cibiru Kota Bandung)". Skripsi ini disusun oleh Cucu Vivi Pratika (2006) Jurusan Komunikasi dan Penyiaran Islam Fakultas Dakwah dan Komunikasi UIN Sunan Gunung Djati Bandung. Skripsi tersebut menggunakan metode deskriptif. Hasil dari penelitian tersebut menemukan bahwa respon mahasiswa terhadap pesan dakwah dalam lagu nasyid Opick bersifat positif. Hal ini dapat dilihat dari indikator perhatian mahasiswa dapat dikatakan cukup baik, indikator pengertian mahasiswa dapat dikatakan baik dan indikator penerimaan mahasiswa dapat dikatakan baik.

Berdasarkan keterangan di atas, penelitian ini memiliki kesamaan 
yaitu tentang respon. Sedangkan yang membedakannya adalah bila Cucu Vivi Pratika ini yang menjadi objeknya mahasiswa dan meneliti tentang pesan dakwah lagu nasyid Opick dan penelitian itu berkaitan tentang perhatian, pengertian, dan penerimaan. Maka penelitian ini yang menjadi objeknya yaitu netizen dan akan meneliti tentang respon netizen terhadap dakwahnya ustadz Arifin Ilham di media sosial Facebook dalam bentuk emotikon dan komentar.

Tujuan dari penelitian ini ialah untuk mengetahui perhatian netizen terhadap dakwah bi al-qalam ustadz Arifin Ilham, untuk mengetahui pengertian atau persepsi netizen terhadap dakwah bi al-qalam ustadz Arifin Ilham, dan terakhir untuk mengetahui penerimaan netizen terhadap dakwah bi al-qalam ustadz Arifin Ilham.

Dari tujuan penelitian di atas, penelitian ini juga memiliki manfaat. Dalam kegunaan penelitian ini dapat diklasifikasikan menjadi dua, yaitu kegunaan teoritis dan kegunaan praktis. Kegunaan teoritis: diharapkan sebagai informasi dan dokumentasi ilmiah, memperkaya kajian tentang ilmu dakwah, serta bermanfaat bagi pengembangan ilmu dakwah khususnya dakwah bi al-qalam di media sosial. Sedangkan kegunaan praktis: diharapkan dapat memberikan gambaran dan wawasan kepada para netizen untuk mengetahui dakwah bi al-qalam di media sosial Facebook.

\section{METODE PENELITIAN}

Metode penelitian yang digunakan dalam penelitian ini adalah analisis isi kualitatif. Pengolahan data dalam penelitian merupakan hal yang sangat penting dan mutlak dilakukan agar data yang diperoleh mempunyai arti, sehingga penelitian yang dilaksanakan dapat memberikan kesimpulan yang benar.

Setelah data-data terkumpul kemudian diolah, selanjutnya dianalisis. Analisis isi didahului dengan melakukan coding terhadap istilah-istilah atau penggunaan kata atau kalimat yang relevan dan yang paling banyak muncul dalam media komunikasi. Dalam hal pemberian coding, perlu juga dicatat konteks mana istilah itu muncul. Kemudian, dilakukan klasifikasi terhadap coding yang telah dilakukan. Klasifikasi dilakukan dengan melihat sejauh mana satuan makna berhubungan dengan tujuan penelitian. Klasifikasi ini dimaksudkan untuk membangun kategori dari setiap klasifikasi. Kemudian, satuan makna dan kategori dianalisis dan dicari hubungan satu dengan lainnya untuk menemukan makna, arti, dan tujuan dari isi komunikasi itu. Hasil analisis ini kemudian dideskripsikan dalam bentuk draf laporan 
penelitian sebagaimana umumnya laporan penelitian (Bungin, 2009: 157).

Menurut Bungin (2009: 159) secara teknik analisis isi mencakup upaya-upaya seperti klasifikasi lambang-lambang yang dipakai dalam komunikasi, menggunakan kriteria dalam klasifikasi, dan menggunakan teknik analisis tertentu dalam membuat prediksi. Peneliti memulai analisisnya dengan menggunakan lambang-lambang tertentu, mengklasifikasi data tersebut dengan kriteria-kriteria tertentu serta melakukan prediksi dengan teknik analisis yang tertentu pula. Berikut adalah gambar teknik analisis isi:

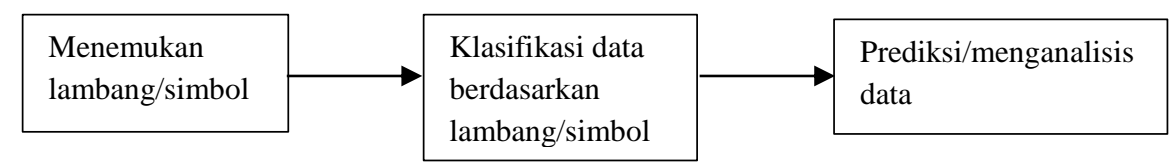

Gambar 1. Teknik Analisis Isi

\section{HASIL DAN PEMBAHASAN}

Ustadz Arifin Ilham di setiap materi yang diposting dalam akunnya selalu bersumber dari Al-Qur'an dan As-Sunnah seperti tentang aqidah, ibadah, dan akhlak. Tapi terkadang juga beliau suka memposting tentang bisnisnya. Walaupun begitu ustadz Arifin Ilham dalam setiap postingan dakwahnya selalu mengandung pesan dakwah yang bernilai positif untuk para netizen yang membacanya. Berikut adalah pengelompokkan pesan dakwah dari akun Facebook ustadz Arifin Ilham berdasarkan tiga kategori:

Tabel 1. Kategori Pesan Dakwah Ustadz Arifin Ilham Di Facebook

\begin{tabular}{ccc}
\hline Aqidah & Ibadah & Akhlak \\
\hline "Manfaat Do'a" & "Penyebab Malas & "Keadaan Umat Manusia Yang \\
"Hikmah Berdzikir" & "Kelahiran Bayi" & Membuat Syetan PESTA PORA" \\
"Kriteria Istri Sholehah" \\
$\begin{array}{c}\text { Varangan Terhadap } \\
\text { "Iman, Ibadah, Amal } \\
\text { Sholeh dan Akhlak } \\
\text { Mulia" }\end{array}$ & - & "Kriteria Suami Sholeh" \\
"Ketaqwaan" & - & "Menikah Karena Allah" \\
\hline
\end{tabular}




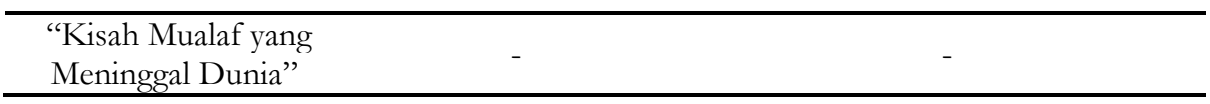

Berdasarkan tabel 1 terdapat tiga pesan dakwah yaitu aqidah, ibadah, dan akhlak. Di luar dari tiga pesan dakwah tersebut ada juga pesan yang disampaikan oleh ustadz Arifin Ilham yaitu pesan bersifat komersil, yaitu iklan produk madu.

Respon merupakan suatu hal yang selalu ada dalam proses kegiatan dakwah baik itu di dunia nyata ataupun di dunia maya. Dengan adanya respon pada pelaksanaan dakwah khususnya di media sosial, berarti dakwah tersebut memang ditanggapi oleh masyarakat (netizen). Respon di media sosial didalamnya mencakupi respon komentar dan emotikon. Untuk mengetahui lebih jelasnya tentang respon dari netizen di media sosial diperlukan sebuah pembatasan dan batasan. Hal tersebut bisa dilihat pada teori S-O-R yang di dalam teori itu terdapat tiga aspek dari respon yaitu perhatian, pengertian, dan penerimaan. Karena dalam kegiatan dakwah di media sosial didalamnya mencakup sebuah pernyataan yang bersifat positif dan negatif.

Dalam teori S-O-R bahwa stimulus atau pesan yang disampaikan kepada komunikan mungkin diterima atau mungkin ditolak. Komunikasi akan berlangsung jika ada perhatian dari komunikan. Proses berikutnya komunikan mengerti. Kemampuan komunikan inilah yang melanjutkan proses berikutnya. Setelah komunikan mengolahnya dan menerimanya, maka terjadilah kesediaan untuk mengubah sikap. Penjelasan tersebut berkaitan dengan tiga aspek yang telah disebutkan di atas yaitu perhatian, pengertian, dan penerimaan (Effendy, 1993: 255).

Jadi, diterima atau tidaknya proses dakwah di media sosial tersebut, bisa dijadikan sebagai sebuah acuan dalam proses dakwah selanjutnya. Demikian pula halnya dengan respon netizen terhadap dakwah ustadz Arifin Ilham di media sosial Facebook dapat djadikan sebagai acuan bagi proses kegiatan dakwah di media sosial pada masa yang akan datang.

Untuk mengetahui kegiatan dakwah di media sosial ini dilakukan penganalisisan terhadap materi, respon komentar, dan emotikon. Lebih jelasnya berikut adalah pemaparan tentang respon netizen yang dilihat dari ketiga aspek yaitu perhatian, pengertian, dan penerimaan.

\section{Perhatian Netizen terhadap Pesan Dakwah Ustadz Arifin Ilham}


Menurut Mubarok (1991: 110) perhatian adalah proses mental dimana kesadaran terhadap stimuli lebih menonjol, dan pada saat yang sama terhadap stimuli yang lain melemah. Jadi, yang dimaksud perhatian dalam penelitian ini, bahwa proses mental para netizen yaitu mereka memberikan kesadarannya dengan cara memberikan tanda emotikon dan komentar. Sehingga semua dianggap sebagai pemberian stimuli yang lebih, sedangkan yang tidak memberikan berarti kesadarannya lemah.

Penelitian ini dibatasi berdasarkan respon netizen pada postingan ustadz Arifin Ilham di bulan Februari. Respon tersebut dilihat berdasarkan jumlah respon emotikon dan jumlah respon komentar.

Pertama, Jumlah Respon Emotikon. Emotikon di media sosial saat ini ada lima jenis yaitu "like (y)", "love" atau "super (<3)", "haha (:D)", "wow $(: \mathrm{O})$ ", "sad (:)", dan "angry (>:O)". Dari masing-masing emotikon tersebut mempunyai arti tersendiri. Emotikon "like (y)" mengungkapkan bahwa orang tersebut menyukai postingan itu, emotikon "love $(<3)$ " berarti ungkapan penuh cinta atau bahagia, emotikon "haha (:D)" untuk mengungkapkan perasaan senangnya, emotikon "wow (:O)" mengungkapkan perasaan terkejut atau kagum, emotikon "sad (:)" ungkapan untuk perasaan sedih, dan terakhir emotikon "angry $(>: \mathrm{O})$ " adalah ungkapan dari perasaan marah dan kesal.

Mark Zuckerberg di akun Facebooknya menyatakan alasan kenapa beliau menyediakan lima emotikon tersebut di Facebook.

Respon emotikon yang diberikan netizen kepada postingan ustadz Arifin Ilham itu beragam tidak hanya dalam satu emotikon saja. Para netizen memberikan respon emotikon sesuai dengan keinginan mereka dan sesuai dengan tema dari postingan tersebut. Berikut adalah tabel dari respon emotikon yang diberikan oleh netizen untuk setiap postingan ustadz Arifin Ilham.

Tabel 2. Jumlah Respon Emotikon

\begin{tabular}{|c|c|c|c|c|c|c|}
\hline \multirow[b]{2}{*}{ Tema } & \multicolumn{6}{|c|}{ Jumlah Emotikon } \\
\hline & $\begin{array}{l}\text { Like } \\
\text { (y) }\end{array}$ & $\begin{array}{c}\text { Super } \\
(<3)\end{array}$ & $\begin{array}{l}\text { Haha } \\
(: D)\end{array}$ & $\begin{array}{l}\text { Wow } \\
(: O)\end{array}$ & $\begin{array}{l}\text { Sad } \\
(\text { (\&) }\end{array}$ & $\begin{array}{c}\text { Angr } \\
\text { y } \\
(>: O)\end{array}$ \\
\hline Manfaat Do'a & 72.144 & 1 & - & - & - & - \\
\hline $\begin{array}{l}\text { Hikmah Berdzikir } \\
\text { Keadaan Umat Manusia }\end{array}$ & 48.798 & - & - & - & - & - \\
\hline $\begin{array}{c}\text { Yang Membuat Syetan } \\
\text { PESTA PORA }\end{array}$ & 38.563 & - & - & - & - & - \\
\hline
\end{tabular}


Siti Tarwiah \& Uwes Fatoni

\begin{tabular}{ccccccc}
\hline Larangan Terhadap & 56.159 & - & - & - & - & - \\
Valentine Day & & & & & & \\
Iman, Ibadah, Amal Sholeh & 31.220 & - & - & - & - & - \\
dan Akhlak Mulia & 25.953 & - & - & - & - & - \\
$\quad$ Ketaqwaan & 70.144 & 1 & - & - & - & - \\
Kriteria Istri Sholehah & 9.208 & 2 & - & - & - & - \\
Madu Az-Zikra & 55.286 & 5 & - & - & - & - \\
Kriteria Suami Sholeh & 20.529 & - & - & - & - & - \\
Masjid Az-Zikra & 27.518 & 1 & - & - & - & - \\
Menikah Karena Allah & 22.004 & 2 & - & - & - & - \\
Penyebab Malas Tahajud & 15.071 & 17 & 5 & - & - & - \\
Santri & 56.713 & 123 & - & - & 71 & - \\
Kisah Mualaf yang & 83.331 & 1.136 & - & 65 & - & - \\
Meninggal Dunia & & & & &
\end{tabular}

Berdasarkan tabel 2. jumlah emotikon "like (y)" yang paling banyak itu tentang kelahiran anak ustadz Arifin Ilham dengan jumlah emotikon tersebut 83.331.

Emotikon "super $(<3)$ " dengan jumlah 1.136 adalah emotikon yang terbanyak dari yang lainnya, dengan topik tentang kelahiran anak ustadz Arifin Ilham dan emotikon "super $(<3)$ " terbanyak.

Emotikon "haha (:D)", dalam emotikon ini hanya ada satu tanggal yang memberi tanda terhadap emotikon tersebut yaitu tentang santri ustadz Arifin Ilham dan video ketika ustadz Arifin Ilham bermain bola bersama santrinya dan jumlah emotikonnya adalah 5 .

Emotikon "wow (:O)" sama seperti emotikon "haha (:D)" karena dalam satu bulan itu hanya ada satu postingan yang memberikan tanda kepada emotikon "wow (:O)", yang membedakan adalah postingannya yaitu tentang kelahiran anak ustadz Arifin Ilham dan jumlah emotikon itu 65.

Terakhir emotikon "sad (:)", netizen yang mengungkapkan perasaan sedihnya dalam bulan itu adalah tentang kisah seorang mualaf yang meninggal dunia dan jumlahnya 71 .

Berdasarkan temuan di atas, perhatian netizen terhadap postingan ustadz Arifin Ilham di Facebook dilihat dari jumlah respon emotikon yang mereka berikan. Emotikon adalah sebuah tanda di media sosial Facebook untuk pengekspresian diri para netizen. Dengan adanya emotikon ini netizen bisa dengan mudah mengekspresikan perasaannya dan pemikirannya terhadap isi postingan termasuk postingan dakwah ustadz 
Arifin Ilham. Emotikon yang paling banyak adalah "like (y)", karena "like (y)" merupakan simbol yang sudah lama digunakan di Facebook. Selain emotikon "like (y)", emotikon "super $(<3)$ " adalah tanda yang juga banyak dipilih oleh netizen, hal ini sesuai dengan yang dikemukakan Mark Zuckerberg (https://www.facebook.com/zuck) bahwa emotikon "super $(<3)$ " menjadi emotikon yang paling sering dipakai oleh pengguna Facebook untuk mengungkapkan perasaannya.

Jumlab Respon Komentar

Komentar dalam media sosial bisa berarti sebuah ungkapan dari netizen terhadap postingan itu. Komentar juga bisa berupa pendapat, kritik, atau saran dari para netizen terhadap suatu postingan di media sosial.

Dalam akun Facebook ustadz Arifin Ilham banyak berbagai macam komentar, ada yang berpendapat, mengkritik, dan lain-lain. Jumlah komentar dari setiap postingan itu berbeda-beda, ada yang ratusan bahkan ada juga yang ribuan. Berikut adalah tabel jumlah komentar dari respon netizen terhadap postingan ustadz Arifin Ilham selama bulan Februari.

Tabel 3. Jumlah Respon Komentar

\begin{tabular}{cc}
\hline Tema & Jumlah Komentar \\
\hline Manfaat Do'a & 2.018 \\
Hikmah Berdzikir & 1.128 \\
Keadaan Umat Manusia Yang & 1.612 \\
Membuat Syetan PESTA PORA & 1.641 \\
Larangan Terhadap Valentine Day & 1.169 \\
Iman, Ibadah, Amal Sholeh dan & 1.203 \\
Akhlak Mulia & 2.532 \\
Ketaqwaan & 351 \\
Kriteria Istri Sholehah & 2.219 \\
Madu Az-Zikra & 752 \\
Kriteria Suami Sholeh & 1.354 \\
Masjid Az-Zikra & 986 \\
Menikah Karena Allah & 662 \\
Penyebab Malas Tahajud & 4.266 \\
Santri & $\mathbf{5 . 7 7 5}$ \\
Kisah Mualaf yang Meninggal Dunia & Kelahiran Bayi
\end{tabular}

Berdasarkan tabel 3 jumlah komentar yang paling banyak itu tentang kelahiran anak ustadz Arifin Ilham dengan jumlah komentar 5.775. Ustadz Arifin Ilham membuat postingan ini untuk memberitahukan bahwa anaknya telah lahir dan yang mengomentarinya banyak. Para netizen memberikan ucapan selamat kepada ustadz Arifin Ilham dan do'a kepada 
Siti Tarwiah \& Uwes Fatoni

anak itu. Berikut adalah gambar dari postingan yang jumlah komentarnya banyak:

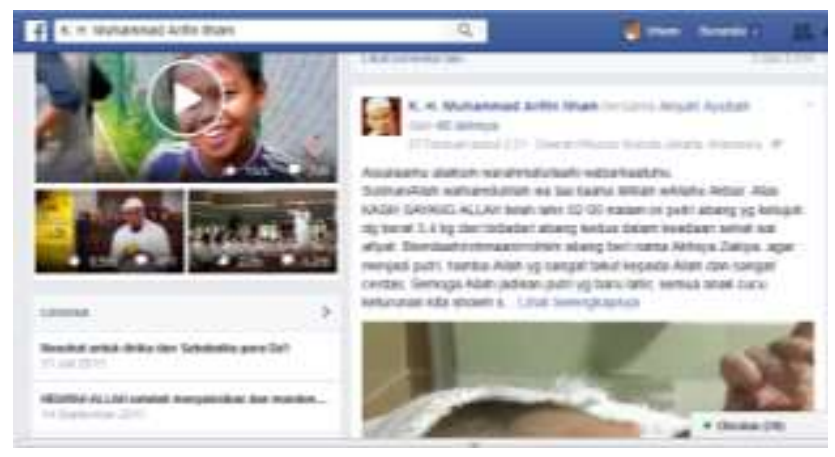

Gambar 2. Postingan Jumlah Komentar Tertinggi

Selanjutnya jumlah komentar yang paling sedikit itu tentang madu Az-Zikra dengan jumlah 351. Komentarnya sedikit dikarenakan postingan ini bukan pesan dakwah yang murni melainkan iklan dan promosi dari bisnisnya ustadz Arifin Ilham. Berikut gambar dari postingan yang jumlah komentarnya paling sedikit:

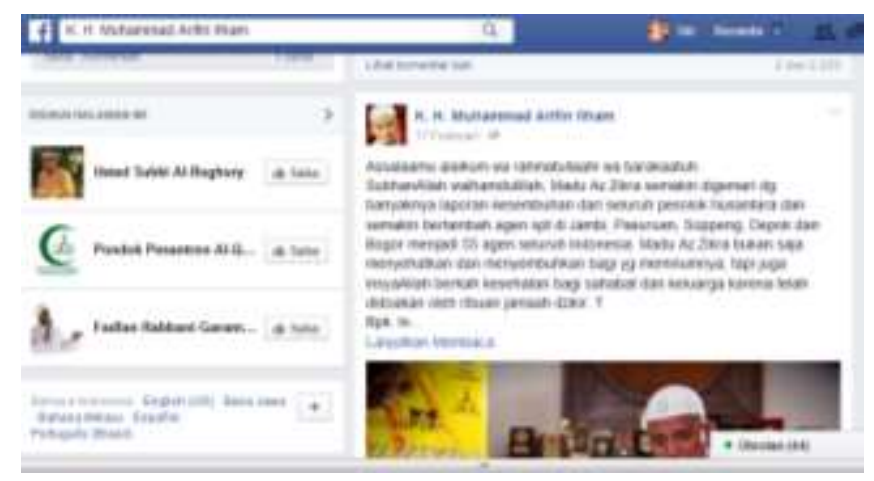

Gambar 3. Postingan Jumlah Komentar Paling Sedikit

Berdasarkan pembahasan di atas, maka bisa dilihat perhatian netizen terhadap postingan ustadz Arifin Ilham itu dalam jumlah respon komentar. Respon komentar ini dilihat dari segi banyak dan sedikitnya jumlah yang mengomentari. Banyak atau sedikitnya yang mengomentari, itu tergantung pada postingan tersebut, apakah sesuai dengan yang diharapkan atau tidak. 
Perhatian bisa datang dari luar (eksternal) dan bisa juga datang dari dalam diri (internal). Dalam penelitian ini perhatiannya datang dari faktor luar (eksternal) dengan prinsip kebaruan, yaitu jumlah isi komentarnya banyak ketika netizen merasa ikut terlibat menjadi bagian dari pesan itu seperti tentang kelahiran bayi ustadz Arifin Ilham, mereka mengungkapkannya bukan hanya melalui simbol emotikon tetapi melalui komentar juga. Ini sesuai dengan aspek respon emotikon bahwa pesan tentang kelahiran bayi mendapatkan jumlah emotikon yang paling banyak. Hal ini sesuai dengan yang dikatakan Faizah dan Lalu (2009: 153) bahwa perhatian dengan prinsip kebaruan itu merupakan segala sesuatu yang bersifat baru akan menarik perhatian netizen seperti tentang kelahiran bayi dalam pesannya ustadz Arifin Ilham. Hal yang bersifat baru ini didalamnya terkandung sebuah penilaian yang berbeda dari biasanya, sehingga dengan hal baru itu netizen ikut terlibat dan memberikan komentar yang banyak.

\section{Pengertian Netizen Terhadap Postingan Akun Facebook Ustadz Arifin Ilham}

Pengertian yaitu hasil berfikir, yang merupakan rangkuman sifat-sifat pokok dari suatu barang kenyataan yang dinyatakan dengan suatu perkataan (Ahmadi, 2003: 169). Pengertian yang dimaksud dalam penelitian ini adalah bahwa hasil berpikir para netizen yaitu dengan memahami isi pesan dari postingan tersebut yang dituangkan kedalam sebuah perkataan atau komentar. Pemahaman tersebut bisa dilihat dari bagaimana para netizen memberikan komentar terhadap postingan itu. Apakah komentar itu bersifat positif, negatif, netral, atau bahkan juga di luar dari pembahasan.

Penulis di sini akan mengambil contoh komentar dari setiap masingmasing komentar yang positif, negatif, netral, dan tidak sesuai tema. Berikut adalah pemaparan komentar para netizen terhadap postingan ustadz Arifin Ilham.

Pertama, Komentar Positif. Komentar positif dalam penelitian ini ialah komentar yang bersifat baik dan tidak menjelek-jelekan dari postingan tersebut. Dalam penelitian ini penulis membagi komentar positif menjadi dua, yaitu komentar positif tingkatan tinggi dan tingkatan biasa.

Komentar positif tingkatan tinggi. Komentar positif tingkatan tinggi ialah komentar yang memberikan ungkapan-ungkapan dzikir seperti menyebutkan kata-kata subhanallah, allabu akbar, alhamdulillah, jazakumullah, masya allah, dan lain-lain. Kata-kata tersebut itu adalah bagian dari dzikir, sehingga ini merefleksikan kespiritualitas dari komentar netizen bahwa mereka memiliki kesadaran yang sangat tinggi berkaitan dengan pesan 
Siti Tarwiah \& Uwes Fatoni

dakwah ini. a) Subhanallah: bisa dilihat dalam komentar netizen kepada postingan ustadz Arifin Ilham yang bertema tentang manfaat do'a, b) Allabu Akbar: bisa dilihat dalam komentar netizen kepada postingan ustadz Arifin Ilham yang bertemakan tentang kisah seorang mualaf yang meninggal dunia, c) Alhamdulillah: bisa dilihat dalam komentar netizen kepada postingan ustadz Arifin Ilham yang bertema tentang masjid AzZikra, c) Jarakumullab: bisa dilihat dalam komentar netizen kepada postingan ustadz Arifin Ilham yang bertema tentang keadaan umat manusia yang membuat setan berpesta pora, d) Masya Allab: bisa dilihat dalam komentar netizen kepada postingan ustadz Arifin Ilham yang bertemakan tentang larangan terhadap valentine day, postingannya terdapat di tanggal 10 Februari.

Komentarpositif tingkatan biasa. Komentar positif tingkatan biasa dalam penelitian ini ialah komentar yang biasa saja dan sederhana dalam komentar itu ada kata amin dan terima kasih. Berikut adalah komentar positif yang biasa. Amin bisa dilihat dalam komentar netizen kepada postingan ustadz Arifin Ilham yang bertema tentang hikmah dari berdzikir. Terima Kasih bisa dilihat dalam komentar netizen kepada postingan ustadz Arifin Ilham yang bertema tentang manfaat dari membaca kalimat "Laa ilaaba illallaabu wahdahu Laa syariika labu, labul mulku wa labul hamdu wa huwa 'ala kulli syai-in qodiir".

Kedua, Komentar Negatif. Komentar negatif dalam penelitian ini yaitu komentar yang secara tidak langsung menjatuhkan isi dari postingan tersebut. Penulis membagi komentar negatif menjadi empat bagian, yaitu kritikan, teguran, sindiran, dan tidak suka. Kritikan bisa dilihat dalam komentar netizen kepada postingan ustadz Arifin Ilham yang bertema tentang manfaat dari membaca kalimat "Laa ilaaha illallaahu wabdabu Laa syariika labu, labul mulku wa labul hamdu wa buwa 'ala kulli syai-in qodiir", postingannya dan komentar ini kritikannya terhadap penulisan. Teguran bisa dilihat dalam komentar netizen kepada postingan ustadz Arifin Ilham yang bertema tentang hikmah dari berdzikir. Sindiran bisa dilihat dalam komentar netizen kepada postingan ustadz Arifin Ilham yang bertema kriteria suami sholeh.

Ketiga, Komentar Netral. Komentar netral ialah komentar yang sifatnya tidak condong kepada salah satu komentar seperti komentar positif dan negatif. Jadi, komentar netral ini bersifat menyeluruh dan berada di tengahtengah antara komentar positif dan negatif. Dalam komentar ini penulis membagi ke dalam dua aspek, yaitu saran dan opini. Saran bisa dilihat dalam 
komentar netizen kepada postingan ustadz Arifin Ilham yang bertema tentang larangan terhadap valentine day. Opini bisa dilihat dalam komentar netizen kepada postingan ustadz Arifin Ilham yang bertemakan tentang keterkaitan antara iman, ibadah, amal sholeh, dan akhlak mulia.

Keempat, Komentar Tidak Sesuai Tema. Komentar tidak sesuai tema ialah komentar yang isi komentarnya tidak membahas masalah yang ada di dalam tema tersebut. Dalam penelitian ini komentar tidak sesuai tema dibagi menjadi tiga, yaitu pertanyaan, iklan (promosi), dan permohonan. Komentar tersebut di antaranya Pertanyaan di luar tema: bisa dilihat dalam komentar netizen kepada postingan ustadz Arifin Ilham yang bertema tentang hikmah dari berdzikir. Iklan (promosi): Yang bersifat promosi itu beragam ada yang mempromosikan barang, jasa, dan juga paytren. Peneliti mengambil satu contoh dari beberapa jenis iklan tersebut, yaitu tentang promosi barang yang bisa dilihat dalam komentar netizen kepada postingan ustadz Arifin Ilham yang bertemakan tentang madu Az-Zikra. Permohonan dido'akan di luar tema: bisa dilihat dalam komentar netizen kepada postingan ustadz Arifin Ilham yang bertemakan tentang masjid Az-Zikra.

Berdasarkan temuan penelitian, proses pemahaman dari masingmasing netizen terhadap pesan dakwah ustadz Arifin Ilham di Facebook itu berbeda. Sehingga menimbulkan tanggapan komentar yang berbeda-beda juga, ada yang baik, buruk, ataupun acuh. Semua itu tergantung dari mereka yang membaca sampai memahami isi pesan tersebut. Hal ini didasari oleh perkataan Faizah dan Lalu (2009: 151) bahwa pengertian atau persepsi adalah sebuah proses pemahaman dari stimulus yang diberikan oleh ustadz Arifin Ilham kepada netizen sehingga mereka memperoleh pengetahuan baru setelah memahaminya. Dengan memperoleh pengetahuan baru itu, kemudian mereka memberikan komentarnya kepada pesan Dakwah tersebut.

\section{Penerimaan Netizen Terhadap Postingan Ustadz Arifin Ilham}

Penerimaan adalah perubahan sikap dari keputusan yang menuju kepada tujuan sikap yang diharapkan. Berhasil atau tidaknya pesan yang disampaikan oleh komunikator dapat digolongkan dalam nilai tinggi, moderat, dan rendah (Mar'at, 1982: 32).

Dalam penelitian yang dimaksud dengan penerimaan yaitu perubahan sikap untuk berubah menjadi lebih baik dari yang sebelumnya. Penerimaan tersebut bisa dilihat dalam komentar yang ingin berubah menjadi baik di setiap postingan ustadz Arifin Ilham. Kategori dalam 
Siti Tarwiah \& Uwes Fatoni

keinginan untuk berubah menjadi baik ini dibagi menjadi tiga, yaitu aqidah, ibadah, dan akhlak. Dilihat dari komentarnya ada keinginan netizen itu untuk terhindar dari aqidah yang menyimpang, semakin rajin beribadah, dan semakin baik akhlaknya. Terhindar dari aqidah yang menyimpang: bisa dilihat dalam komentar netizen kepada postingan ustadz Arifin Ilham yang bertemakan tentang larangan terhadap hari valentine. Semakin rajin beribadah: bisa dilihat dalam komentar netizen kepada postingan ustadz Arifin Ilham yang bertemakan tentang hikmah dari berdzikir. Semakin baik akhlaknya: bisa dilihat dalam komentar netizen kepada postingan ustadz Arifin Ilham yang bertemakan tentang keadaan umat manusia yang membuat setan berpesta pora.

Berdasarkan pembahasan di atas, maka bisa dilihat penerimaan netizen terhadap postingan ustadz Arifin Ilham ialah keinginan keinginan untuk berubah menjadi lebih baik, yaitu terhindar dari aqidah yang menyimpang, semakin rajin beribadah, dan semakin baik akhlaknya. Penerimaan netizen dalam bentuk perubahan ini dikatakan berhasil, berati postingan ustadz Arifin llham bukan hanya sekedar postingan biasa tetapi postingan tersebut masuk ke dalam hati mereka. Sehingga setelah membaca postingan itu mereka tersentuh dan ingin berubah menjadi lebih baik lagi. Hal ini sesuai dengan pendapat Faizah dan Lalu (2009: 158) bahwa penerimaan yang akan masuk ke dalam hati itu tidak terlepas dari faktor bahasa, karena bahasa adalah alat yang paling penting dalam berdakwah. Ustadz Arifin Ilham menggunakan bahasa yang dimengerti oleh netizen, sehingga netizen bisa membacanya dengan baik sampai masuk ke dalam hati mereka.

\section{PENUTUP}

Berdasarkan hasil penelitian penulis memperoleh kesimpulan, yaitu perhatian netizen terhadap dakwah bi al-qalam ustadz Arifin Ilham di media sosial Facebook dilihat dari respon emotikon dan komentar, karena emotikon dan komentar merupakan bentuk dari ekspresi para netizen terhadap postingan ustadz Arifin Ilham di media sosial Facebook. Pengertian netizen terhadap postingan ustadz Arifin Ilham berdasarkan isi komentar mereka. Komentar para netizen itu bisa dilihat berdasarkan empat bentuk. a) komentar positif terdiri dari komentar tingkat tinggi yaitu pengucapan kata subhanallah, alhamdulillah, allahu akbar, jazakumullah, masya allah dan komentar tingkat biasa yaitu pengucapan kata amin dan terima kasih. b) komentar negatif terdiri dari kritikan, teguran, sindiran, dan tidak 
suka. c) komentar netral terdiri dari saran dan opini. d) komentar tidak sesuai dengan tema terdiri dari pertanyaan di luar tema, iklan (promosi), dan permohonan dido'akan. Penerimaan netizen terhadap postingan ustadz Arifin Ilham dapat dilihat dari segi komentar netizen terhadap postingan tersebut. Maksudnya ialah perubahan ke arah yang lebih baik lagi. Dalam penelitian ini terbagi ke dalam tiga kategori yaitu aqidah, ibadah, dan akhlak. Hal ini terlihat dari komentar netizen yang ingin terhindar dari aqidah yang menyimpang, semakin rajin beribadah, dan semakin baik akhlaknya.

Implikasi dari penelitian ini terdapat saran, yaitu kepada pengelola akun Facebook ustadz Arifin Ilham, untuk tambah bervariasi dan kreatif lagi dalam menentukan tema yang akan dipostingkan. Sehingga netizen tidak merasa bosan untuk selalu mengikuti dari setiap pesan dakwah yang disampaikan melalui status akun Facebook tersebut. Kepada jamaah ustadz Arifin Ilham di media sosial Facebook hendaklah mengikuti dari setiap postingannya secara konsisten, rajin, penuh dengan semangat, niat yang ikhlas dengan tujuan menuntut ilmu agar diridhoi oleh Allah SWT. Serta perlu ditingkatkan kembali kesadaran jamaah Facebook ustadz Arifin Ilham dalam menanggapi dari setiap pesan dakwahnya, agar berusaha dengan segala kemampuan untuk mengaplikasikannya dalam kehidupan seharihari, sehingga tidak hanya dalam komentar (ucapan) saja. Kepada peneliti berikutnya yang akan meneliti akun Facebook ustadz Arifin Ilham hendaklah meneliti tentang pesan dakwahnya dari aspek yang lain, seperti apa saja isi pesan dakwah yang disampaikan, lebih banyak pesan apa yang disampakan, dan menggunakan metode apa dalam menyampaikan pesan dakwahnya.

\section{DAFTAR PUSTAKA}

Al-Hasani, S. M. A. A. (2006). Kiat Sukses Berdakwah, Jakarta: Amzah. Amin, S. M. (2008). Rekonstruksi Pemikiran Dakwah Islam, Jakarta: Amzah. Bale Bandung. (2015). Kabupaten dan Kota Bandung Pengguna Medsos Terbesar di Jabar, diakses 11 Agustus 2015, dari http://www.balebandung.com.

Bungin, B. (2009). Penelitian Kualitatif, Jakarta: Kencana.

Effendy, O. U. (1993). Ilmu, Teori dan Filsafat Komunikasi, Bandung: Citra Aditya Bakti.

Faizah. \& Effendi, L. M. (2009). Psikologi Dakwah, Jakarta: Kencana. Indosiar. (2015). Korban Penculikan Via Facebook. Alami Depresi Pasca Kasusnya Merebak, diakses 11 Agustus 2015, dari http://www.indosiar.com. 
Siti Tarwiah \& Uwes Fatoni

Kamil, R. (2014). Tetot: Aku, Kamu, dan Media Sosial, Bandung: Sygma.

Kusnawan, A. Dkk. (2009). Dimensi Ilmu Dakwah, Bandung: Widya Padjadjaran.

Mar'at. (1982). Sikap Manusia Perubahan Serta Pengukurannya, Jakarta: Ghalia. Mubarok, A. (1991). Psikologi Dakwah, Jakarta: Pustaka Firdaus.

Nasrullah, R. \& Sari, N. I. (2012). Komik sebagai Media Dakwah: Analisis Semiotika Kepemimpinan Islam dalam Komik "Si Bujang". Ilmu Dakwah: Academic Journal for Homiletic Studies 6 (1) 24-40

Nistanto, R. K. (2014). Facebook Ungkap Jumlah Penggunanya di Indonesia, diakses $11 \quad$ Agustus 2015, dari http://tekno.kompas.com/read/2014/09/22/15205237/facebook. ungkap.jumlah.penggunanya.di.indonesia.

Pranoto, P. (2015). Cewek Belia Ini Hijrah ke Klaten Lalu Jual Diri Lewat Facebook, diakses 11 Agustus 2015, dari http://jogja.tribunnews.com/2015/05/12/cewek-belia-ini-hijrahklaten-lalu-jual-diri-lewat-facebook.

Putra, Y. M. P. (2015), Polisi Bekuk Pelaku Penipuan Via Facebook, diakses 11 Agustus 2015, dari http://www.republika.co.id/berita/nasional/daerah/15/02/06/njc gm6-polisi-bekuk-pelaku-penipuan-via-facebook.

Saputra, W. (2011). Pengantar Ilmu Dakwah, Jakarta: PT Raja Grafindo Persada.

Tasmara, T. (1997). Komunikasi Dakwah, Jakarta: Gaya Media Pratama.

Utari, P. (2011). Media Sosial, New Media dan Gender dalam Pusaran Teori Komunikasi. Bab Buku Komunikasi 2.0: Teoritisasi dan Implikasi, Yogyakarta: Aspikom. 